\title{
PENGGUNAAN MEDIA GAMBAR DALAM MENINGKATKAN MINAT BELAJAR SISWA KELAS IV DI SD NEGERI 3 RANOMEETO
}

\author{
Apriani Safitri, Kabiba \\ Universitas Muhammadiyah Kendari \\ apriani.safitri87@yahoo.com, wabiba64@gmail.com
}

\begin{abstract}
ABSTRAK
Media pembelajaran berupa gambar merupakan alat bantu yang dapat digunakan guru dalam proses pembelajaran dengan tujuan untuk membentuk pembelajaran yang bermakna bagi peserta didik. Sehingga peran dari seorang guru yang memiliki keahlian, ketepatan dan kemampuan dalam penggunaan media tersebut sangat berpengaruh pada terbentuknya minat belajar pada peserta didik. Penelitian ini bertujan untuk mendeskripsikan penggunaan media gambar dalam meningkatkan minat belajar siswa kelas IV di SD Negeri 3 Ranomeeto. Jenis penilitian ini adalah penelitian kualitatif yakni peneliti menggambarkan penggunaan media gambar dalam meningkatkan minat belajar siswa kelas IV di SD Negeri 3 Ranomeeto melalui wawancara mendalam pada informan penelitian yang didukung dengan proses pengamatan dan dokumentasi. Subjek penelitian yaitu kepala sekolah, guru kelas IV, 3 orang guru mata pelajaran dan seluruh siswa kelas IV yang berjumlah 21 orang. Teknik analisis data yang digunakan yaitu dengan alur, yang meliputi reduksi data, penyajian data, dan tahap verifikasi.

Hasil penelitian menunjukan bahwa strategi guru dalam menggunakan media gambar dalam meningkatkan minat belajar siswa kelas IV di SD Negeri 3 Ranomeeto yakni; menyesuaikan materi dengan gambar yang akan digunakan, merancang media gambar yang akan digunakan mengingat keterbatasan media, menyusun langkah-langkah dalam menggunakan media gambar, menyesuaikan langkah-langkah pembelajaran berdasarkan RPP, referensi dan tujuan pembelajaran yang telah disusun sebelumnya.
\end{abstract}

Katakunci: Media Gambar, Minat Belajar

\section{ABSTRACT}

Learning media in the form of pictures is a tool that can be used by teachers in the learning process with the aim of forming meaningful learning for students. So the role of a teacher who has the expertise, accuracy and ability to use the media is very influential in the formation of learning interest in students. This research is aimed at describing the use of picture media in increasing the interest in learning for IV class students at SD Negeri 3 Ranomeeto. This type of research is a qualitative study in which the researcher describes the use of image media in increasing the interest in learning of IV class students in The research subjects were the principal, grade IV teachers, 3 subject teachers and all class IV students totaling 21 people.Data analysis technique used is the flow, which includes data reduction, data presentation, and verification stage.

The results showed that: the teacher's strategy in using picture media in increasing learning interest of IV class students at at SD Negeri 3 Ranomeeto namely; adjusting the material with the pictures to be used, designing media images that will be used given the limitations of the media, compiling steps in using media images, adjusting learning steps based on lesson plans, references and learning objectives that have been prepared previously.

Keywords: picture media, learning interest 


\section{PENDAHULUAN}

Media

pembelajaran

merupakan salah satu komponen dalam pendidikan yang ikut menentukan keberhasilan dalam proses pembelajaran. Sehingga bagi tenaga pendidik perlu memahami penggunaan media pembelajaran dengan menyesuaikan materi yang akan diajarkan. Selain itu, pembelajaran akan jauh lebih bermakna apabila peserta didik ikut terlibat dalam setiap proses pembelajaran, peserta didik tidak hanya dijadikan sebagai objek pembelajaran tetapi juga sebagai subjek yang dapat menentukan arah dan proses pembelajaran. Dalam hal ini, tenaga pendidik perlu menyusun dan melaksanakan kegiatan belajar mengajar dimana peserta didik dapat aktif membangun pengetahuannya sendiri. Hal ini sesuai dengan pandangan konstruktivisme yaitu keberhasilan belajar tidak hanya bergantung pada lingkungan atau kondisi belajar, tetapi juga pada aspek psikologis peserta didik.

Aspek psikologis yang sangat berpengaruh dalam proses pembelajaran peserta didik adalah minat belajar. Minat ini erat kaitannya dengan perasaan terutama perasaan senang. Siswa yang berminat terhadap pelajaran akan tampak terus tekun belajar. Sebaliknya siswa yang rendah minat belajarnya tidak antusias dalam mengikuti proses pembelajaran. Penggunaan media pembelajaran memiliki andil yang cukup besar dalam menumbuhkan minat belajar siswa dalam kegiatan belajar mengajar. Kemampuan menangkap pelajaran oleh peserta didik dapat dipengaruhi dari pemilihan media pembelajaran yang tepat, sehingga tujuan pembelajaran yang ditetapkan akan tercapai. Terdapat berbagai macam media pembelajaran yang dapat dijadikan alternatif bagi tenaga pendidik untuk menjadikan kegiatan pembelajaran di kelas berlangsung efektif dan optimal. Salah satunya yaitu dengan menggunakan media pembelajaran berbasis teknologi.

Sebagaimana penelitian yang telah dilakukan oleh Juliana (2016), dengan menggunakan media gambar dalam dalam peningkatan minat belajar fiqih siswa Kelas IV MIN Ulee Kareng dengan hasil penelitian bahwa strategi penerapan media gambar dalam peningkatan minat belajar siswa kelas IV MIN Ulee Kareng yaitu: melaksanakan langkah-langkah kegiatan yang tercantum dalam RPP, menjelaskan materi, menyiapkan bahan diskusi, melakukan diskusi, memberi pertanyaan serta penguataan terhadap materi dan melakukan kegiatan evaluasi. Aktivitas guru dalam menggunakan media gambar adalah sangat baik artinya penggunaan media gambar dapat meningkatkan minat belajar siswa pada pembelajaran Fikih. Selanjutnya penelitian yang dilakukan oleh Rini Intansari dengan menggunakan media gambar untuk 
meningkatkan keterampilan bercerita siswa kelas IV SD Negeri 2 Tanjung Senang Bandar Lampung tahun 2017 dengan hasil penelitian menunjukkan bahwa pada siklus I penggunaan media gambar dapat meningkatkan aktivitas belajar meliputi aspek bertanya sebesar $61,54 \%$, menjawab pertanyaan $38,46 \%$, diskusi $53,85 \%$, bekerjasama $46,15 \%$ dan bercerita sebesar 53,85\%. sedangkan pada siklus II aktivitas belajar meliputi aspek bertanya sebesar $84,61 \%$, menjawab pertanyaan $69,23 \%$, diskusi $88,46 \%$, bekerjasama $76,92 \%$ dan bercerita sebesar 92,31\%. Ratarata keterampilan bercerita siswa siklus 1 meliputi aspek kesesuaian gambar sebesar 57,69\%, ketepatan cerita 50\%, keberanian 42,31, ketepatan kalimat $38,46 \%$ dan kelancaran bercerita sebesar $34,62 \%$. Sedangkan pada siklus II keterampilan bercerita meliputi kesesuaian gambar sebesar 75,01\%, ketepatan cerita 69,23\%, keberanian 73,07\%, ketepatan kalimat $42,31 \%$ dan kelancaran bercerita sebesar 50\%.Maka dapat dikatakan bahwa hasil intervensi tindakan yang diharapkan telah tercapai.

Dengan demikian, pembelajaran dengan menggunakan media sebagai penghantar materi dapat menjadi salah satu alternatif keberhasilan proses belajar-mengajar karena melalui pembelajaran yang aktif akan mampu meningkatkan efektivitas pembelajaran.

Pembelajaran dengan menggunakan media yang tepat akan mengutamakan kerjasama antar peserta didik untuk mencapai tujuan pembelajaran. Menggunakan media pembelajaran dapat mengubah peran tenaga pendidik, dari yang berpusat pada tenaga pendidiknya ke pengelolaan peserta didik yang aktif. Salah satunya adalah penggunaan media gambar dalam memberikan stimulus respon pada peningkatan minat belajar siswa. Melalui gambar dapat menghantarkan materi yang bersifat abstrak menjadi konkrit.

Berdasarkan hasil pengamatan yang dilakukan oleh peneliti di SD Negeri 3 Ranomeeto, Kecamtan Ranomeeto, Kabupaten Konawe Selatan, ditemukan bahwa situasi proses pembelajaran yang dilakukan oleh beberapa guru di SD Negeri 3 Ranomeeto masih belum dilaksanakan secara optimal, permasalahan yang paling mendasar dalam proses pembelajaran yang dilakukan oleh guru adalah minat belajar siswa yang rendah yakni dapat dilihat dari proses pembelajaran, siswa cepat bosan, jenuh, serta sulit menerima pelajaran yang disampaikan oleh guru. Siswa yang bosan akan mengalami kejenuhan dan pada akhirnya mereka kehilangan perhatian selama proses pembelajaran. Apabila guru masih menggunakan paradigma pembelajaran lama dalam arti komunikasi dalam pembelajaran cenderung berlangsung satu arah umumnya dari guru ke siswa, guru 
lebih mendominasi pembelajaran tanpa menggunakan media sebagai alat bantu dalam menyampaikan pesan dari materi pembelajaran, maka pembelajaran cenderung monoton sehingga mengakibatkan siswa merasa jenuh dan membosankan.

Oleh karena itu, dalam membelajarkan berbagai mata pelajaran kepada peserta didik, guru hendaknya lebih memilih berbagai variasi pendekatan, strategi, metode dan media yang sesuai dengan situasi sehingga tujuan pembelajaran yang direncanakan akan tercapai. Perlu diketahui bahwa baik atau tidaknya suatu pemilihan media pembelajaran akan tergantung tujuan pembelajarannya, kesesuaian dengan materi pembelajaran, tingkat perkembangan peserta didik, kemampuan tenaga pendidik (guru) dalam mengelola pembelajaran serta mengoptimalkan sumber-sumber belajar yang ada.

\section{Pembelajaran}

dengan

menggunakan media gambar memiliki manfaat yang sangat besar pada siswa SD yakni memberikan kesempatan kepada peserta didik untuk lebih mengembangkan kemampuannya dan menelaah setiap objek pembelajaran yang diberikan. Hal ini dikarenakan dalam kegiatan pembelajaran, peserta didik dituntut untuk lebih aktif dalam belajar melalui kegiatan belajar secara langsung.

Menurut Sadiman (2003) media gambar adalah suatu gambar yang berkaitan dengan materi pelajaran yang berfungsi untuk menyampaikan pesan dari guru kepada siswa. Media gambar ini dapat membantu siswa untuk mengungkapkan informasi yang terkandung dalam masalah sehingga hubungan antar komponen dalam masalah tersebut dapat terlihat dengan lebih jelas. Sedangkan menurut Hamalik (2004) media gambar adalah segala sesuatu yang diwujudkan secara visual ke dalam bentukbentuk dimensi sebagai curahan ataupun pikiran yang bermacam-macam seperti lukisan, potret, slide, film, proyektor.

Berdasarkan pengertian di atas maka dapat disimpulkan bahwa media gambar adalah media yang paling umum dipakai dalam proses pembelajaran. Hal ini dikarenakan siswa lebih menyukai gambar, apalagi jika dibuat gambar yang berwarnawarni dan disajikan sesuai dengan kondisi dan kemampuan anak didik. Tentu media gambar tersebut akan menambah semangat siswa dalam mengikuti proses pembelajaran.

Adapun macam-macam media gambar menurut Arikunto (2010), ada empat macam gambar yang dapat digunakan dalam pembelajaran, yaitu sebagai berikut: 1) Gambar gabungan, yaitu gambar tunggal yang luas atau besar yang memperlihatkan sebuah pemandangan (rumah sakit dan pantai) dimana sejumlah orang dapat dilihat sedang melakukan sesuatu. 2) Gambar seri, yaitu sejumlah gambar berantai untuk membentuk serial 
seperti gambar aktivitas sehari-hari dari mulai bangun tidur sampai tidur lagi. 3) Gambar individual, yaitu gambar tunggal tentang benda, orang atau kegiatan. Gambar ini ukurannya bervariasi. 4) Gambar khusus (poster, peta, grafik, iklan dan brosur). Dengan menggunakan media gambar diharpkan mampu meningkatkan minat belajar siswa dalam proses pembelajaran.

Rahman dan Muhib (2009), minat belajar dapat digolongkan menjadi beberapa macam, antara lain:

a. Berdasarkan tumbuhnya minat dapat dibedakan menjadi dua, yaitu: (1) minat primitif yakni minat yang timbul karena kebutuhan biologis atau jaringan-jaringan tubuh. (2) minat sosial yakni minat yang timbul karena proses belajar, minat ini tidak secara langsung berhubungan dengan kita sendiri.

b. Berdasarkan arahnya, minat dapat dibedakan menjadi dua, yaitu: (1) minat intrinsik, yakni minat yang langsung berhubungan dengan aktivitas itu sendiri, ini merupakan minat yang paling mendasar. (2) minat ekstrinsik yakni minat yang berhubungan dengan tujuan akhir dari kegiatan yang dilakukan.

Yohana (2016), media merupakan komponen yang berupa alat pembelajaran yang berfungsi melancarkan jalannya kegiatan belajar mengajar. Melalui penggunaan media pembelajaran diharapkan dapat mempertinggi proses belajar mengajar yang pada akhirnya dapat mempengaruhi kualitas hasil belajar siswa. Bahkan diatur dalam PP No.19 Tahun 2005 tentang Standar Nasional Pendidikan, Pasal 42 Ayat 1, disebutkan bahwa "Setiap satuan pendidikan wajib memiliki sarana yang meliputi perabot, peralatan pendidikan, media pendidikan, buku dan sumber bahan lainnya, bahan habis pakai, serta perlengkapan lain yang diperlukan untuk menunjang proses pembelajaran yang teratur dan berkelanjutan".

Menurut Apriani dan Nurmayanti (2018), minat belajar merupakan landasan penting bagi seseorang untuk melakukan kegiatan dengan baik. Minat tidak hanya dapat mempengaruhi tingkah laku seseorang tetapi juga dapat mendorong orang untuk tetap melakukan dan memperoleh sesuatu. Dengan demikian penggunaan media gambar merupakan sarana yang mampu mendorong terciptanya minat belajar siswa dalam mengikuti pembelajaran. Terbentuknya minat balajar siswa diharapkan dapat mendorong meningkatnya hasil dan pretasi yang dicapai siswa.

Berdasarkan pendapat yang dikemukakan di atas maka dapat disimpulkan bahwa penggunaan media gambar yang memadai memungkinkan terjadinya proses belajar terlaksana secara maksimal. Hal ini dapat ditunjukan dari minat 
belajar siswa yang meningkat sehingga akan berdampak pada capaian hasil belajar siswa. Dengan demikian, melalui penggunaan media pembelajaran diharapkan dapat mempertinggi keaktifan siswa dalam proses belajar mengajar yang dapat ditunjukkan melalui meningkatnya minat belajar siswa.

Adapun tujuan dalam penelitian ini adalah sebagai berikut: Untuk mendeskripsikan penggunaan media gambar dalam meningkatkan minat belajar siswa kelas IV di SD Negeri 3 Ranomeeto.

\section{METODE PENELITIAN}

Penelitian ini dilaksanakan di SD Negeri 3 Ranomeeto yang berlokasi di Jln. Kendari-Motaha, Desa Duduria, Kecamatan Ranomeeto, Kab. Konawe Selatan. Jenis penelitian yang digunakan adalah penelitian kualitatif melalui pendekatan deskriptif. Menurut Sukardi, (2003) penelitian kualitatif melalui pendekatan deskriptif merupakan metode penelitian yang berusaha menggambarkan dan menginterpretasi objek sesuai dengan apa adanya. Dengan metode ini penulis dapat menganalisa dan memberikan gambaran tentang objek sesuai dengan kondisi sebenarnya. Maksudnya adalah untuk memperoleh gambaran yang sebenarnya antara keserasian teori dan praktek tentang penggunaan media gambar dalam meningkatkan minat belajar siswa kelas IV di SD Negeri 3 Ranomeeto.

Teknik yang digunakan dalam mengumpulkan data dalam penelitian ini adalah observasi, wawancara dan dokumentasi. Teknik analisis yang digunakan dalam penelitian ini Menurut Sugiyono, (2014), yaitu dilakukan dengan alur yang meliputi pengumpulan data, reduksi data, penyajian data, dan tahap verifikasi atau penarikan kesimpulan.

\section{HASIL DAN PEMBAHASAN}

Penggunaan Media Gambar dalam Proses Pembelajaran Siswa Kelas IV Di SD Negeri 3 Ranomeeto

Penggunaan media gambar merupakan salah satu cara yang digunakan oleh guru dalam mentransformasi sebuah materi pembelajaran menjadi sebuah materi yang menarik dan mudah dipahami. Melalui media gambar, pesan yang disampaikan oleh guru akan lebih mudah diserap oleh peserta didik. Sebagaimana hasil pengamatan yang dilakukan di SD Negeri 3 Ranomeeto dalam proses pembelajaran di kelas IV ditemukan bahwa dalam pelaksanaan proses pembelajaran yang dilakukan oleh guru di dalam kelas belum menggunakan media pembelajaran secara optimal dalam menghantarkan materi. Hal ini disebabkan karena, SD Negeri 3 Ranomeeto belum memiliki ketersediaan media pembelajaran yang cukup untuk dipergunakan dalam proses pembelajaran. Pada 
umumnya guru menggunakan media gambar dalam bentuk gambar datar yakni organ tubuh manusia yang dibuat secara mandiri oleh siswa pada mata pelajaran IPA, kubus pada mata pelajaran matematika, peta, sistem tata surya dan globe pada mata pelajaran IPS yang telah tersedia di dalam kelas. Para guru belum menggunakan media gambar berbasis teknologi dalam proses pembelajaran yang dikarenakan belum tersedinya LCD dan infokus, bahkan di setiap kelas belum tersedia aliran listrik.

Serupa dengan hasil wawancara pada kepala sekolah, guru dan siswa yang ditemukan bahwa penggunaan media gambar sebagai penghantar materi dengan tujuan meningkatkan minat belajar siswa kelas IV di SD Negeri 3 Ranomeeto belum terlaksana secara optimal. Hal ini dikarenakan ketersediaan media gambar masih sangat terbatas yakni media gambar datar. Untuk media gambar yang diproyeksikan belum digunakan oleh guru dalam mengajar disebabkan belum tersedianya LCD dan Infokus bahkan aliran listrik belum menjangkau keseluruh kelas, sehingga guru masih mengalami kesulitan dalam penggunaannya. Keberadaan media belajar yang berada di dalam kelas merupakan hasil kreativitas guru dan siswa yang dapat digunakan setiap harinya dalam merangsang siswa untuk senantiasa mengikuti pembelajaran secara aktif dan kreatif.

Berdasarkan pemaparan tersebut, dapat disimpulkan bahwa penggunaan media gambar sebagai penghantar materi dengan tujuan meningkatkan minat belajar siswa kelas IV di SD Negeri 3 Ranomeeto belum terlaksana secara optimal. Hal ini dikarenakan ketersediaan media gambar masih sangat terbatas yakni media gambar datar. Media gambar yang digunakan oleh guru bertujuan untuk memudahkan guru dalam mengkonstruksi materi pembelajaran menjadi sesuatu yang nyata, sehingga siswa tidak dibuat menghayal, mereka secara langsung melihat materi yang sedang dipelajari. Dengan demikian, media merupakan kebutuhan pokok bagi guru dalam melaksanakan pembelajaran. Keberadaan media gambar dalam pembelajaran sangat penting bagi guru dan bagi siswa, sehingga sekolah dan dinas terkait tentunya memperhatikan kebutuhan guru dan siswa di dalam kelas sehingga mendorong terciptanya minat belajar siswa yang berdanpak pada peningkatan prestsi belajar siswa.

Media gambar merupakan media yang sederhana yang digunakan oleh guru, tidak membutuhkan proyektor dan layer. Media ini tidak tembus cahaya, maka tidak dapat dipantulkan pada layer. Guru memilih ini karena praktis. Akan tetapi seiring perkembangan 
teknologi, media gambar dapat diproyeksikan dalam bentuk visual. Sebagaimana yang dijelaskan oleh Hamalik (2004) media gambar adalah segala sesuatu yang diwujudkan secara visual ke dalam bentuk-bentuk dimensi sebagai curahan ataupun pikiran yang bermacam-macam seperti lukisan, potret, slide, film, proyektor.

Menurut Hamzah (Haryanti, 2018) yang menyatakan gambar/foto termasuk ke dalam media visual. Media ini berfungsi untuk menyalurkan pesan dari penerima sumber ke penerima pesan. Pesan yang akan disampaikan kedalam simbol-simbol komunikasi visual, simbol tersebut perlu dipahami dengan benar, artinya agar proses penyampaian pesan dapat berhasil dengan baik dan tidak menimbulkan kesalahan. Menurut Intansari (2017), bahwa manfaat gambar sebagai media visual antara lain:

a. Menimbulkan daya tarik bagi siswa. Gambar dengan berbagai warna akan lebih menarik dan dapat membangkitkan minat serta perhatian siswa.

b. Mempermudah pengertian siswa. Suatu penjelasan yang sifatnya abstrak dapat dibantu dengan gambar sehingga siswa lebih mudah memahami apa yang dimaksud.

c. Memperjelas bagian-bagian penting. Melalui gambar dapat pula memperbesar bagian-bagian yang penting atau yang kecil.
Sehingga dapat diamati lebih jelas

d. Menyingkat suatu uraian panjang.

Selain itu, para guru dalam merancang media gambar perlu memperhatikan isi materi, konten gambar yang akan digunakan dan cara menyajikan media gambar sehingga proses pembelajaran dapat menjadi aktif dan menyenangkan bagi siswa. Sudjana dan Rivai (2013), ada beberapa prinsip/kriteria penggunaan media yang perlu dipedomani oleh guru dalam proses belajar mengajar yaitu :

a. Ketepatan dengan tujuan pembelajaran, artinya media pembelajaran dipilih atas dasar tujuan-tujuan instruksional yang telah ditetapkan

b. Dukungan terhadap isi bahan pembelajaran, artinya bahan pelajaran yang sifatnya fakta, prinsip yang sangat memerlukan bantuan media agar mudah dipahami siswa

c. Kemudahan memperoleh media, artinya media yang diperlukan mudah memperolehnya, setidaktidaknya dapat dibuat oleh guru pada saat mengajar atau mungkin sudah tersedia di sekolah

d. Keterampilan guru dalam menggunakan media, apapun jenis media yang diperlukan syarat utama adalah guru harus dapat menggunakan dalam proses pembelajaran

e. Tersedianya waktu untuk menggunakannya, sehingga media 
tersebut dapat bermanfaat bagi siswa pada saat pelajaran berlangsung

f. Sesuai dengan taraf berfikir siswa sehingga makna yang terkandung didalamnya dapat dipahami siswa.

Berdasarkan pemaparan di atas, maka dapat disimpulkan bahwa dengan menggunakan media gambar, guru merasa dipermudah dalam menghantarkan materi dalam proses belajar mengajar, selain itu siswa juga marasa tertarik untuk mengikuti proses pembelajaran, pembelajaran tidak membosankan karena siswa secara langsung melihat tema atau topik yang sedang dibahas oleh guru melalui gambar, sehingga siswa dapat memahami materi yang disampaikan oleh guru. Media gambar disajikan sesuai dengan kondisi dan kemampuan anak didik. Selain itu, dengan penggunaan media gambar akan menambah semangat siswa dalam mengikuti proses pembelajaran di dalam kelas.

\section{Strategi Guru Menggunakan Media} Gambar dalam Meningkatkan Minat Belajar Siswa Kelas IV Di SD Negeri 3 Ranomeeto

Penggunaan media gambar merupakan salah satu strategi yang digunakan guru agar siswa lebih memahami materi yang akan diberikan dan lebih menarik lagi dalam proses pembelajaran, sehingga siswa tidak bosan selama proses pembelajaran berlangsung, minat belajar siswa mengalami peningkatan yang ditunjukan melalui keterlibatan dan keaktifan siswa.

Berdasarkan hasil pengamatan yang dilakukan di kelas IV SD Negeri 3 Ranomeeto, strategi guru dalam menggunakan media gambar dalam meningkatkan minat belajar siswa, yakni:

a. Menyesuaikan materi dengan gambar yang akan digunakan.

b. Merancang media gambar yang akan digunakan.

c. Menyusun langkah-langkah dalam menggunakan media gambar.

d. Menyesuaikan langkah-langkah pembelajaran berdasarkan RPP, referensi dan tujuan pembelajaran yang telah disusun sebelumnya.

Penggunaan media gambar dalam proses pembelajaran di dalam kelas dilaksanakan dengan cara; (1) guru memaparkan materi dan memberikan masalah kepada siswa, selanjutnya siswa menyelesaikan masalah yang diberikan guru secara berkelompok. (2) guru menunjukan gambar yang berkaitan dengan materi dan selanjutnya dideskripsikan oleh siswa. (3) guru mengarahkan siswa untuk menggambar berdasarkan tema atau materi pembelajaran. Respon siswa terhadap penyajian pelajaran dengan menggunakan media gambar yang dilakukan oleh guru bahwa siswa sangat antusias mengikuti proses pembelajaran di dalam kelas ketika guru menggunakan gambar sebagai 
penghantar materi dalam proses menulis pembahasan yang diberikan belajar mengajar dan sebaliknya siswa cenderung mengalami oleh guru.

Adapun media gambar yang kebosanan dalam mengikuti proses pembelajaran apabila guru hanya menyampaikan materi dengan berceramah atau siswa hanya
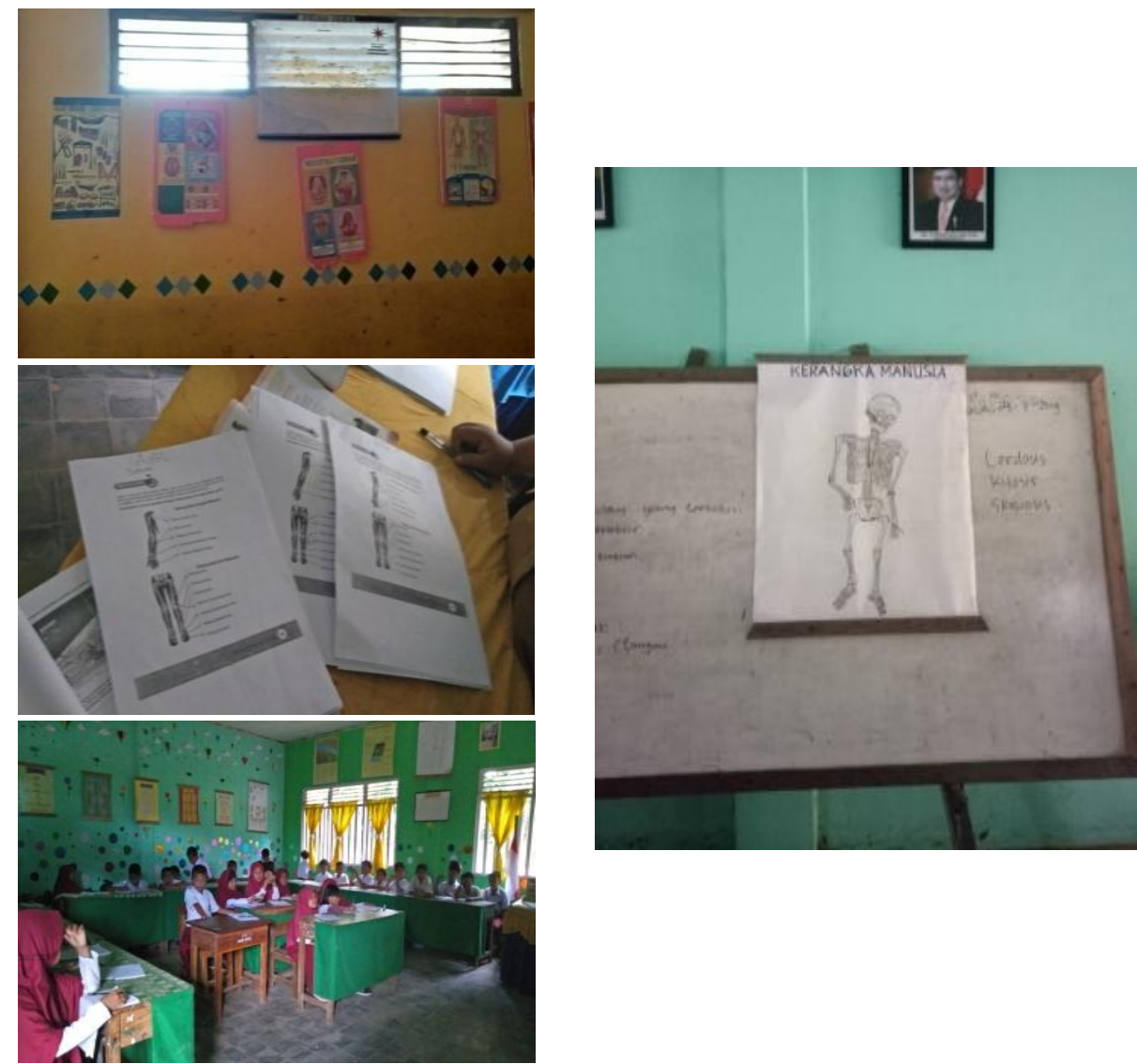

Gambar 1. Media Gambar yang Digunakan Oleh Guru

Berdasarkan gambar di atas, terlihat bahwa media gambar yang digunakan oleh guru kelas IV di SD Negeri 3 Ranomeeto masih sangat sederhana, para guru sekreatif mungkin dalam menyediakan media gambar dengan tujuan untuk menarik minat belajar siswa, selain itu kenyamanan siswa dalam belajar melalui pengaturan posisi duduk sehingga kemajuan belajar siswa terpantau secara menyeluruh.

Hasil wawancara kepala sekolah, guru dan siswa memberikan informasi bahwa penggunaan media gambar dalam pembelajaran merupakan alternatif untuk meningkatkan minat belajar siswa. Hal tersebut dapat dibuktikan dengan keantusiasan siswa dalam mengikuti 
proses pembelajaran yang dapat dilihat dari meningkatnya aktivitas siswa di dalam kelas dan sesering mungkin melakukan interaksi terhadap guru pada setiap proses pembelajaran dengan menggunakan media gambar.

Berdasarkan hasil pengamatan, wawancara dan dokumentasi, dapat disimpulkan bahwa strategi guru dalam menggunakan media gambar yang dilakukan dengan cara (1) menyesuaikan materi dengan gambar yang akan digunakan. (2) merancang media gambar yang akan digunakan. (3) menyusun langkahlangkah dalam menggunakan media gambar. (4) menyesuaikan langkahlangkah pembelajaran berdasarkan RPP, referensi dan tujuan pembelajaran yang telah disusun sebelumnya dapat meningkatkan minat belajar siswa. Hal tersebut dapat dibuktikan dengan keantusiasan siswa dalam mengikuti proses pembelajaran yang dapat dilihat dari meningkatnya aktivitas siswa di dalam kelas dan sesering mungkin melakukan interaksi terhadap guru pada setiap proses pembelajaran dengan menggunakan media gambar, siswa lebih mudah memahami dan menguasai materi pembelajaran.

Diharapkan dengan adanya penggunaan media gambar dapat mendorong dan memotivasi siswa dalam proses belajar mengajar sehingga dapat meningkatkan minat belajar dalam proses belajar mengajar. Melalui penggunaan media gambar, diharapkan dalam pembelajaran memiliki tujuan:

a. Pengajaran akan menarik siswa sehingga dapat menimbulkan motivasi belajar.

b. Bahan pengajaran akan lebih jelas maknanya, sehinga dapat dipahami siswa.

c. Metode pengajaran menggunakan media gambar tidak hanya berkomunikasi verbal melalui penuturan kata-kata guru sehingga siswa tidak bosan.

d. Dengan penggunaan media gambar ini diharapkan siswa dapat melaksanakan kegiatan belajar, sebab tidak hanya mendengarkan.

e. Dengan penggunaan media gambar ini diharapkan siswa dapat melaksanakan kegiatan belajar, sebab tidak hanya mendengarkan uraian guru. Tetapi juga aktivitas lain seperti mengamati, melakukan, mendemonstrasikan dan lainlain. (Depdikbudnas. 2003)

Setyani (2016), memaparkan bahwa salah satu kunci penting agar dapat meningkatkan minat belajar dan memudahkan siswa menerima pesan mengenai materi pelajaran adalah dengan penggunaan media pembelajaran yang menarik dan menyenangkan dalam setiap kegiatan pembelajaran. Dalam menyampaikan pesan dan informasi mengenai materi pelajaran harus menggunakan media 
pembelajaran yang tepat. Apabila media yang digunakan dalam proses pembelajaran tepat dan menyenangkan maka minat belajar akan tumbuh dalam diri setiap siswa dan informasi mengenai materi pelajaran akan tersampaikan kepada siswa. Jika setiap siswa memiliki minat untuk belajar, maka proses pembelajaran akan berjalan dengan kondusif sebab siswa akan mengikuti kegiatan pembelajaran dengan sungguh-sungguh.

\section{SIMPULAN}

Berdasarkan hasil penelitian yang dilakukan di SD Negeri 3 Ranomeeto yakni penggunaan media gambar dalam meningkatkan minat belajar siswa kelas IV dapat disimpulkan bahwa: (1) penggunaan media gambardalam proses pembelajaran masih belum optimal, guru hanya menggunakan media gambar datar yang sangat sederhana yang lebih mudah digunakan, murah dalam mengadakannya dan siswa secara langsung dalam membuat media gambar yang kemudian dijadikan sebagai media pembelajaran, belum menggunakan media gambar yang diproyeksikan yang dikarenakan keterbatasan alat atau media pendukung, (2) strategi guru dalam menggunakan media gambar dalam meningkatkan minat belajar siswa, yakni; menyesuaikan materi dengan gambar yang akan digunakan, merancang media gambar yang akan digunakan mengingat keterbatasan media, menyusun langkah-langkah dalam menggunakan media gambar, menyesuaikan langkah-langkah pembelajaran berdasarkan RPP, referensi dan tujuan pembelajaran yang telah disusun sebelumnya. Melalui strategi tersebut, penggunaan media gambar yang digunakan oleh guru dalam proses pembelajaran dapat meningkatkan minat belajar siswa yakni siswa sangat antusias dalam mengikuti proses pembelajaran, terlibat dan aktif melakukan Tanya jawab, siswa lebih mudah memahami dan menguasai materi pembelajaran, interaksi aktif antara guru ke siswa, siswa ke guru dan siswa ke siswa.

\section{DAFTAR PUSTAKA}

Arikunto, Suharsimi. 2010. Prosedur Penelitian Suatu pendekatan Praktek. Jakarta: Rineka Cipta.

Depdiknas. 2003. Kamus Besar Bahasa Indonesia. Jakarta: Balai Pustaka.

Hamalik, Oemar. 2003. Proses Belajar Mengajar. Jakarta: Rineka Cipta.

Haryanti, Ade Siti. 2018. Jurnal: Penggunaan Media Gambar Dan Media Radio Pada Pembelajaran Menulis Deskripsi Siswa Kelas X SMA Tunas Harapan Balaraja-Tangerang. Jurnal Kredo Vol. 1 No. 2 April 2018. 
Intansari, Rini. 2017. Skripsi: Penggunaan Media Gambar Untuk Meningkatkan Keterampilan Bercerita Siswa Kelas IV SD Negeri 2 Tanjung Senang Bandar Lampung. Fakultas Keguruan Dan IImu Pendidikan Universitas Lampung Bandar Lampung.

Juliana, 2016. Skripsi: Penggunaan Media Gambar Dalam Dalam Peningkatan Minat Belajar Fiqih Siswa Kelas IV MIN Ulee Kareng. Fakultas Tarbiyah Dan Keguruan Universitas Islam Negeri ArRaniry Darussalam-Banda Aceh

Noviyanti, Yohana Budi dkk. 2016. Artikel: Pengaruh Minat Belajar Siswa dan Media Pembelajaran Terhadap Hasil Belajar Mata Pelajaran Teknologi Informasi. Pendidikan Ekonomi-BKK Administrasi Perkantoran, Fakultas Keguruan dan Imu Pendidikan. Universitas Sebelas Maret. Surakarta.

Rahman, Abdul dan Muhib, Abdul Wahab. 2009. Psikologi suatu Pengantar dalam Prespektif Islam. Jakarta: Kencana.

Sadiman, Arief S. 2003. Media Pendidikan. Jakarta: Raja Grafindo Persada.

Safitri, Apriani dan Nurmayanti. 2018. Faktor-Faktor Yang Mempengaruhi Minat Belajar Masyarakat Bajo. Universitas Muhammadiyah Surabaya: Jurnal Pendidikan dan IImu Pengetahuan (Didaktis).
Setyani, Ricka Intan. 2016. Artikel: Hubungan Antara Pemanfaatan Media Pembelajaran Dan Minat Belajar Dengan Hasil Belajar Sosiologi Siswa Kelas Xi IPS SMA Negeri Kebakkramat Tahun Pelajaran 2015/2016. Fakultas Keguruan Dan IImu Pendidikan. Universitas Sebelas Maret. Surakarta

Sudjana, Nana dan Rivai, A. 2013. Media Pengajaran, Bandung : Sinar Baru Algesindo.

Sugiyono. 2014. Metode Penelitian Pendidikan Pendekatan Kuantitatif, Kualitatif Dan R\&D. Bandung: Alfabeta.

Sukardi. 2003. Metodologi Penelitian Pendidikan Kompetensi dan Prakteknya. Jakarta: Bumi Aksara

Undang-Undang Republik Indonesia No 20 Tahun 2005 Tentang Sistem Pendidikan Nasional (Sisdiknas). 